\title{
Creating a Path by Walking It - A Year in ReVIeW OF PoHNA: KeEPERS OF THE Fire
}

\author{
KAREN ERICKSON, ${ }^{*}$ PATTI LABOUCANE-BENSON, ${ }^{* *}$ \\ AND FIONA HOSSACK ${ }^{* * *}$
}

\begin{abstract}
Youth involvement in criminal activity and gangs is a complex problem. This article examines Pohna: Keepers of the Fire, a gang intervention and diversion program for at risk youth. The program seeks to guide at risk youth away from criminal activity by creating $a$ place where youth are valued and their strengths are used to build their connections and responsibilities to the community. There is no simple and straightforward answer to addressing the problem of youth involvement in criminal activity and gangs. However, from our analysis of five case studies, we have learned that in order to develop effective programs and interventions for at risk youth, we need to focus our attention on learning from them and our interactions with them. To effectively support the youth involved in Pohna, we need to understand and address the broader forces at work that both strengthen and undermine their resiliency.
\end{abstract}

Les jeunes impliqués dans les activités criminelles et le gangstérisme représentent un problème complexe. Cet article porte sur Pohna: Keepers of the Fire, programme d'intervention et de diversion de gangs pour les jeunes à risque. Le but du programme consiste à éloigner les jeunes à risque d'activités criminelles en créant un endroit où ils sont valorisés et où leurs forces sont utilisées pour nouer des relations et des responsabilités à l'égard de la communauté. Il n'y a pas de réponse simple et claire au problème de la délinquance juvénile et du gangstérisme. Cependant, l'analyse de cinq études de cas nous a appris que pour développer des programmes et des interventions efficaces pour les jeunes à risque, nous devons apprendre à les connaitre et à interagir avec eux. Pour bien supporter les jeunes qui participent au programme Pohna, nous devons comprendre et aborder les grandes forces en jeu qui, à la fois, renforcent et sapent leur capacité de récupération.

\section{TABLE OF CONTENTS}

I. InTRODUCTION . . . . . . . . . . . . . . . . . . . . . . . . . . . . 946

II. The Program . . . . . . . . . . . . . . . . . . . . . . . . . . . . . . . . . . 948

III. THE LIVES OF Youth INVOLVED IN POHNA $\ldots \ldots \ldots \ldots \ldots \ldots \ldots \ldots$

A. Colby: Chronic OfFENDER (30 Charges) . . . . . . . . . . . 949

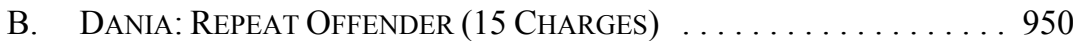

C. JACEY: CRIMINAL ACTIVITY AND

Mental Health Concerns $\ldots \ldots \ldots \ldots \ldots \ldots . \ldots . \ldots . \ldots 92$

D. JOHN: MINOR CHARGES AND THE EXTRAJUDICIAL

SANCTIONS PROGRAM . . . . . . . . . . . . . . . . . . . . . . . . . 954

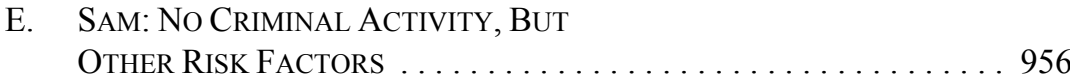

IV. LESSONS LEARNED AND IMPLICATIONS FOR PRACTICE

AND PRogram DESIGN $\ldots \ldots \ldots \ldots \ldots \ldots \ldots \ldots \ldots \ldots \ldots$

* BSW (Victoria); M. Ed. (Toronto). Karen is the Manager of Pohna: Keepers of the Fire at Native Counselling Services of Alberta. Prior to this she was the Manager for Community Solution to Gang Violence, a collaborative community-based initiative in Edmonton.

** Ph.D. Human Ecology (Alberta); Director of Research, Training and Communication of Native Counselling Services of Alberta. Patti has initiated and led many community-based, applied research projects within the Aboriginal community, and is also the General Editor of the periodical Pimatisiwin: A Journal of Ingidenous and Aboriginal Community Health Research.

*** $\quad$ B.A. (Alberta). Fiona is currently pursuing a M.Sc. in Agricultural and Resource Economics from the Faculty of Agricultural, Life \& Environmental Sciences at the University of Alberta. 

A. Colby: Untangling the Web, OVERCOMING THE PAST $\ldots \ldots \ldots \ldots \ldots \ldots \ldots \ldots \ldots$
B. Dania: Keeping the Hope of Change Alive, TRACKING SMALl StEPS OF PROGRESS . . . . . . . . . . . . . . 959
C. JACEY: NAVIGATING INTERACTIONS WITH SYSTEMS . . . . . . . . . . . . . . . . . . . . . . . . . . . . . . . . 959
D. John: DeVeloping A SENSE OF AgENCY AND CONTROL . . . . . . 959

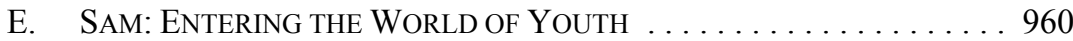

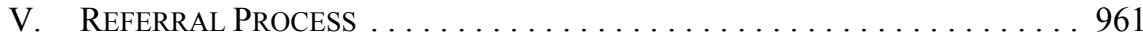
VI. ENGAGING AND SUPPORTING FAMILIES . . . . . . . . . . . . . . . 961
VII. DEALING WITH YOUTHS' VULNERABILITY CONTEXT . . . . . . . . . . . . . 962
VIII. CONCLUSION: ACTION, LEARNING, AND CHANGE . . . . . . . . . . . . 963

\title{
I. INTRODUCTION
}

\begin{abstract}
During ceremonies or gatherings in the Cree community, young people are called upon to start the fire and ensure it is tended to and kept burning. This is a very important job as ceremonies and gatherings would be impossible without proper fire. When the Elders call "Pohna," the young people know what to do - they accept their responsibilities and see how their job is an important part of the community gathering. They know they are valued and needed. ${ }^{1}$
\end{abstract}

Drawing on this metaphor, Pohna: Keepers of the Fire (Pohna), a gang intervention and diversion program for youth, seeks to create a place where youth are valued and their strengths are used to build their connections and responsibilities to the community.

This program was created as the result of a request by the Edmonton Police Service (EPS) for community support to find a way to intervene with Edmonton youth aged 11-17 that were involved in criminal and gang-related activity. While these youth were not formally connected to street gangs and organized criminal networks, they were engaged in a variety of criminal activities (for example, swarming, personal robberies, assault, theft, and the selling of drugs). Many of them wore colours and had rituals and behaviours that seemed to be modelled after Los Angeles gangs - giving themselves names like the Bloodz, Blood Set Soldiers, King Pin Blood, and Blood Tie Family. The EPS did not want to rely on enforcement alone as a way to intervene in the lives of these youth, but wanted a more dynamic, responsive, and integrated approach in order to prevent them from becoming entrenched in further gang activity, association, and lifestyle.

Native Counselling Services of Alberta (NCSA) took the lead in developing a program for these youth. This was partially because the majority of at risk youth identified by the EPS were of Aboriginal descent and partially because the NCSA has developed partnerships with a number of government agencies, schools, and community service organizations through their involvement with the Community Solution to Gang Violence (CSGV). ${ }^{2}$ While the

Native Counselling Services of Alberta, Pohna: Keepers of the Fire (Program Brochure).

The CSGV is a collaborative initiative that works on developing "a strategic, community-wide approach to address the issue of gangs and gang violence" in the City of Edmonton: Karen Erickson, Patti LaBoucane-Benson \& Jana Grekul, The Community Solution to Gang Violence: A Collaborative Community Process and Evaluation Framework (Ottawa: Public Safety Canada, 2007) at 1, online: Native Counselling Services of Alberta $<$ http://www.ncsa.ca/documents/CSGV_Collaborative_Report. pdf $>$. 
NCSA is responsible for the day-to-day operations of the program, it is also supported by a number of partners ${ }^{3}$ who provide advice and support to the program as well as entry points for linkages into their systems. These connections and partnerships enable the program to reach across mandates and "wrap" a comprehensive array of individualized services and support networks around at risk youth to respond to their unique needs, strengths, and interests.

Across the province of Alberta — indeed, across the country — other police services are noticing similar trends in their communities, and other community-based organizations are developing programs to respond to youth deemed at risk for criminal activity and gang involvement. Gangs have existed in Canada for some time, but a comprehensive understanding of the formation of gangs, why youth become involved in them, and how to respond to this involvement is relatively new. For the most part, the communities' understanding of gangs is drawn from newspaper headlines depicting acts of gang violence, high profile arrests of gang members, and "gangsta movies" from the United States. Underneath all of this, police, parents, youth workers, teachers, probation officers, lawyers, and judges deal with the realities of gangs on a daily basis through their interactions with individual youth. There is a gap between the public perception of gangs and the lived reality of the gang phenomenon. If we are to close this gap, practitioners need to begin documenting their practice and share their experience with others, and researchers need to connect with practitioners to help contextualize the struggles and approaches for dealing with the day-today realities of gangs. In this way, we can begin to develop a collective understanding of gangs to inform policies, programs, and practices aimed at addressing youth gangs in Canada. Further, we can move beyond reactions to headlines in newspapers and towards addressing the realities in our communities.

This article draws from an evaluation of the program's first year of operation and the developmental work the authors have done with the NCSA to establish the program. ${ }^{5}$ It provides an account of how our understanding of the problems and issues that surround these youth grew and how the program changed and evolved over time. It unpacks our experiences in working with youth and seeks to draw connections between the realities surrounding young people and our attempts to help them create a different future for themselves - a future in which criminal and gang activity is not a reality. It does not provide a blueprint for responding to at risk youth, but sheds some light on the realities and challenges that we have discovered in delivering the program. Part II of this article provides a brief overview of the orientation, intent, and approach of the program. Part III consists of case studies of five youth involved in the program to provide the context in which the program operates; where concepts meet reality. Part IV describes what we have learned from these youth and the implications of this learning for our practice and program design. The article concludes by suggesting that finding effective interventions for at risk youth depends on our ability to critically examine and adjust our practices and programs as we deliver services to youth.

The key partners include the EPS, Edmonton Public Schools, Edmonton Catholic Schools, Alberta Children and Youth Services, the Edmonton Young Offender Centre, the Edmonton Attendance Centre, the Crown Prosecutor's Office, the Youth Criminal Defence Office, the City of Edmonton, and the CSGV.

Erickson, LaBoucane-Benson \& Grekul, supra note 2 at 2.

Patti LaBoucane-Benson et al., Pohna: Keepers of the Fire Developmental and Formative Evaluation Report 2009-2010 (2010) [unpublished, on file with the authors]. 


\section{The Program}

The program is based on research demonstrating that positive outcomes are more likely to occur when a variety of supports and services are "wrapped around" youth to address their unique needs and circumstances. It is also based on research which shows that the best way to engage youth is to empower them to create change, build their resilience to deal with the challenges they face, and surround them with supportive adults. In particular, it is grounded in an Aboriginal-specific theoretical framework of family resilience whereby the more connected youth are to their family, their community, the natural environment, and the cosmos, the more resilient they will be. ${ }^{6}$

Guided by this framework, the program strives to prevent the future recruitment of youth into street gangs and organized criminal networks in the Edmonton area, and redirect youth currently involved in criminal and gang activity away from further engagement and entrenchment in the gang lifestyle.

Youth are the driving force of the program. They identify the goals that they want to set, how they can meet these goals, and what help they need in order to do so. With their direct participation, the program works to create a "Circle of Support" around youth to help them make positive changes in their lives. It may involve working with schools to increase their attendance and connection, connecting the youth and their family to Aboriginal culture and teachings, and/or getting youth involved in recreation and the arts. The specific services and supports that the program provides depend upon the individual needs and interests of the participants.

\section{The Lives of Youth Involved In PoHnA}

Although the circumstances and realities of the youth involved in Pohna naturally vary from individual to individual, there are also some commonalities. They have all been referred to Pohna because they are either involved or are at risk of becoming involved in criminal and gang-related activity and want to make some positive changes in their lives. Their degree of involvement in criminal activity and gang association varies, and an analysis of the circumstances surrounding their lives appear to fit within five categories: chronic offenders; repeat offenders; criminal activity and mental health concerns; minor charges, leading to involvement in the Extrajudicial Sanctions Program; and no offences, but other risk factors for criminal activity and gang association. To provide context for understanding the operation of the program and the lessons learned through our experience, we have provided the following case studies that reflect the range of youth involved in Pohna. ${ }^{7}$ The names in the case studies have been changed to protect the individuals' privacy. 


\section{A. Colby: Chronic OfFender (30 Charges)}

Colby, age 15, was referred to Pohna by his probation officer. The probation officer referred him to the program because, despite a fairly extensive criminal history, Colby wanted to create some changes in his life. Colby's criminal record includes 30 charges under several different Acts and codes. Under the Criminal Code, ${ }^{8}$ Colby has twice been charged with assault with a weapon or assault causing bodily harm, five times with robbery, twice with theft under $\$ 5,000$, possession of stolen property under $\$ 5,000$, possession of an unauthorized weapon or device, possession of break-in instruments, mischief, as well as a multitude of breach charges. He has also been charged with possession of controlled substances under the Controlled Drugs and Substances $A c t^{9}$ and has five failure to comply charges under the Youth Criminal Justice Act. ${ }^{10}$ As a result, Colby has spent 74 days in remand in the last year and is currently on probation for some of his charges. As the Youth Support Coordinator worked to develop a relationship with Colby and gain some understanding of Colby's life, the challenges he faced, the strengths he held, and the support he had to draw upon, the following picture emerged:

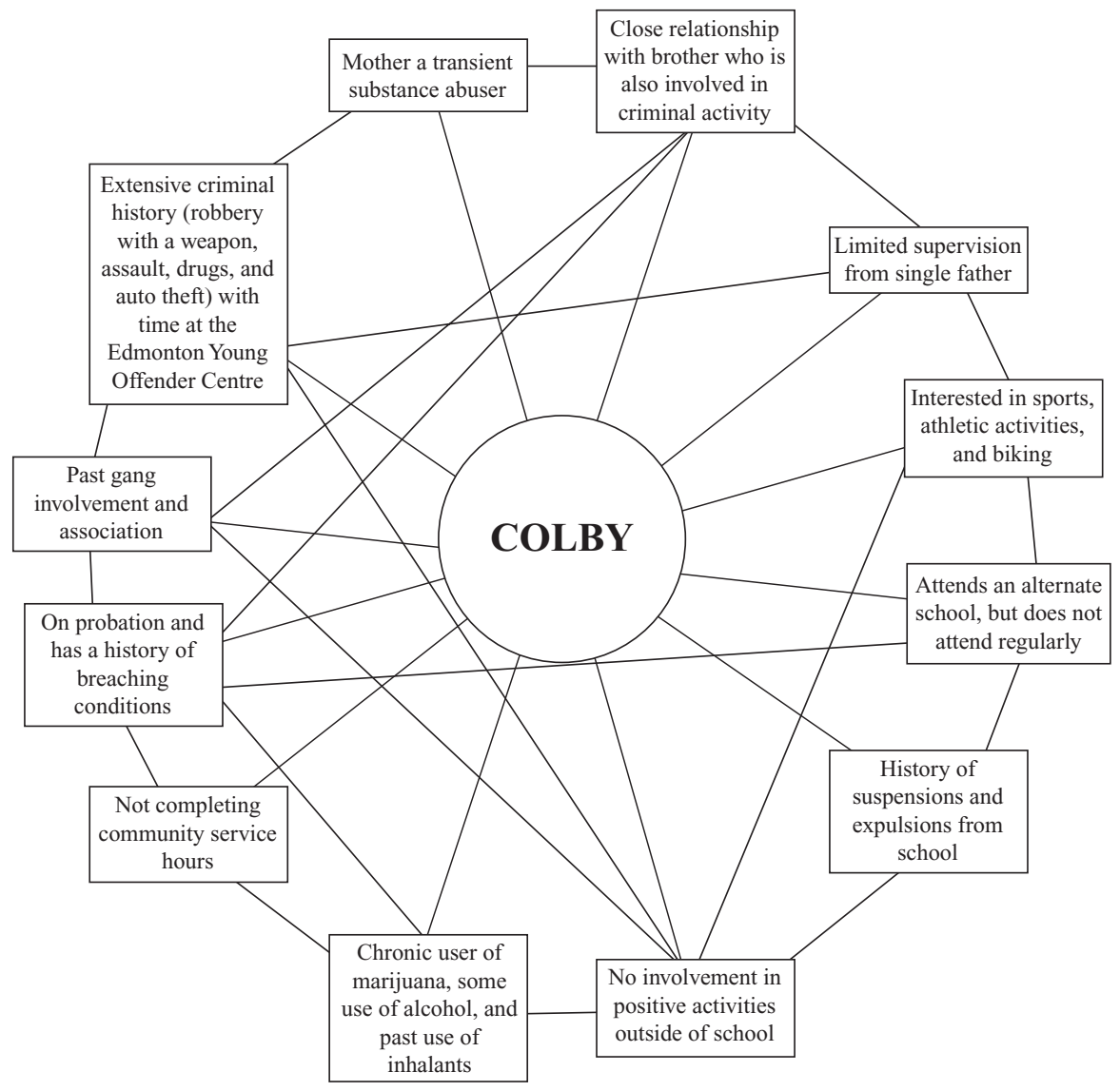

R.S.C. 1985 , c. C-46.

S.C. 1996 , c. 19.

S.C. 2002 , c. 1 . 
Despite Colby's desire to create changes in his life, this will require untangling this web of interconnected and interrelated issues. Principal among these issues is Colby's involvement in criminal activity and the youth justice system. When Colby became involved with Pohna, the courts placed him on probation on the condition that he keep the peace and be of good behaviour; live with his father; be at his residence between 10:00 p.m. and 7:00 a.m.; make reasonable efforts to enroll in and attend school; not use or possess alcohol or non-prescription drugs of any kind; take counselling and assessment as directed by his probation officer; complete 100 non-residence community service hours; and refrain from possessing firearms, prohibited weapons, or ammunition.

If Colby failed to meet these conditions, he was likely to face incarceration at the Edmonton Young Offender Centre (EYOC). However, with over 30 criminal charges and a history of criminal activity and association with criminally involved peer, such as his brother, a central challenge for Colby was to find a way to chart a new path. How does he leave this lifestyle, these codes of behaviour, and his friendships behind him? How does he open himself up to other possibilities and experience other ways of interacting with others?

On a very concrete level, responses to these questions led Colby and his Youth Support Coordinator to create a plan that would allow Colby to meet the conditions of his probation. This plan involved negotiating an agreement whereby Colby would work on increasing his attendance at school. To support these efforts, the Youth Support Coordinator takes time to visit Colby at school, talk to his teachers, and generally show an interest in how Colby is doing at school. These are interactions that help keep most kids connected to school. While attendance is still an issue for Colby, he has attended school more often since his involvement in Pohna.

Another condition that they addressed was the completion of community service hours. The Youth Support Coordinator negotiated with the Attendance Centre that the hours spent with him can be counted as community service hours. Upon learning that Colby was interested in athletics and working out, the Youth Support Coordinator arranged for Colby to volunteer at a boxing club as part of his community service hours. The Youth Support Coordinator has talked to Colby about the importance of maintaining his curfew and keeping the peace but, aside from support and encouragement, this is a condition that Colby must largely meet on his own.

The Youth Support Coordinator has only been working with Colby for two months and the process of helping him move away from the past and towards the future will require a great deal of work. Colby is in real danger of breaching the conditions of his probation. The road ahead will be fraught with challenges, but the journey has started.

\section{B. DANiA: REPEAT OFFENDER (15 CHARGES)}

Dania, age 16, was referred to Pohna by the EPS. Dania was 15 years old when she was first involved with the criminal justice system. Dania has a criminal record that includes two charges of theft under $\$ 5,000$, the assault of a police officer, robbery, meal by fraud, two breaches, possession of a weapon, trespass, obtaining alcohol as a minor, and two charges of shoplifting. She has been on probation for ten months, but may have that extended as she 
is still working on completing 60 hours of community service as part of her sentence. She was also sentenced to two months in custody.

As the Youth Support Coordinator worked to develop a relationship with Dania and gain some understanding of her life, the challenges she faced, the strengths she held, and the support she had to draw upon, the following picture emerged:

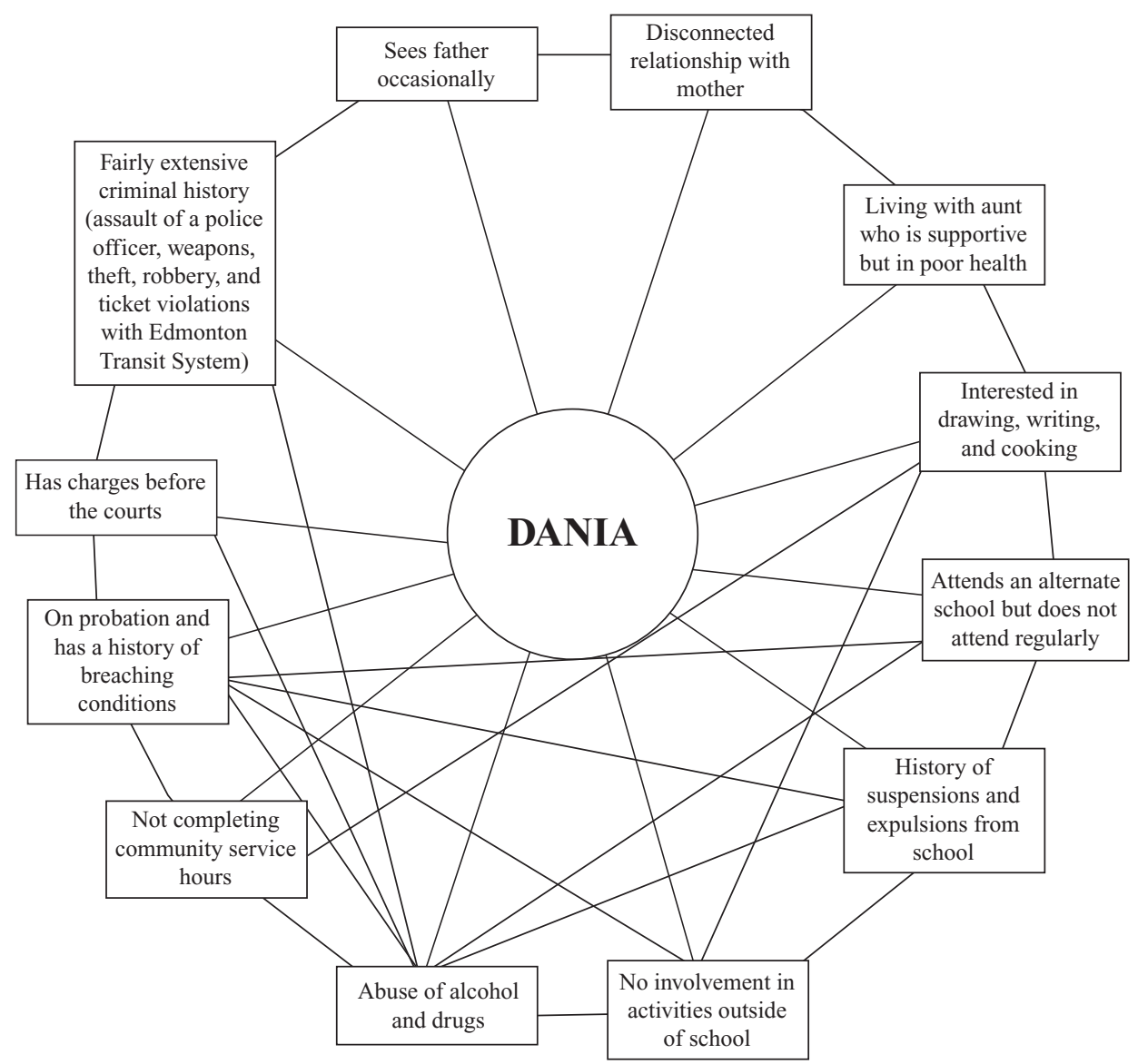

When she became involved in Pohna, Dania said that she wanted to create some changes in her life. Specifically, she wanted to meet the conditions of her probation. The Youth Support Coordinator began working with Dania in these areas and, to date, their interactions have revolved around helping her get to school, attending court hearings, and working on meeting her conditions of probation. The Youth Support Coordinator has also talked to Dania about her use of alcohol and the impact that it is having on her life. As a result of these discussions, Dania has agreed to meet with a drug and alcohol counsellor. 
However, despite Dania's intentions to create changes in her life, and the Youth Support Coordinator's attempts to support her, Dania continues to struggle and seems to be in a downward spiral. As this article was being written, Dania had been expelled from school, was facing additional criminal charges, and was continuing to use alcohol to the point of blacking out. As Dania is facing serious charges for the assault of a police officer, there is a good chance that she will be placed in custody at the EYOC if she is not able to turn things around.

It is uncertain as to what will happen with Dania over the next few months. We do not know whether Dania will be able to pull herself out of this downward spiral, or if we will be able to help her pull out. The Youth Support Coordinator is committed to being with Dania no matter what happens. If Dania decides to see a drug and alcohol counsellor, the Youth Support Coordinator will take her there. When Dania goes to court, the Youth Support Coordinator will be there. If Dania is sent to EYOC, the Youth Support Coordinator will visit her there. The Youth Support Coordinator will not give up on her and Dania will not be left alone to face these challenges.

\section{JaCey: Criminal ACtivity and Mental Health Concerns}

Jacey, age 14, was referred to Pohna by a member of the EPS. Jacey was 12 years old when she first became involved with the criminal justice system. Jacey has three counts of assault, including the assault of a police officer, and a causing of a disturbance charge on her record. As a result, she was on probation for a year with the conditions that she would abide by a curfew, attend school, refrain from drinking and drug use, and complete 50 community service hours. In addition to her past charges, the police have been involved in two cases where she was a missing juvenile.

Over the course of nine months, the Youth Support Coordinator worked to establish a relationship that enabled her to understand what was happening in Jacey's life, and bit by bit the following picture emerged as illustrated in the chart below.

As the Youth Support Coordinator began to gain a deeper understanding of Jacey's situation, it became apparent that interactions with both the criminal justice and the education systems have had a significant impact on her. Not only did she need to find a way to navigate around the structures and processes of these systems, she needed to find a way to manage and deal with the relationships of people within and around these systems. Jacey was not completing her community service hours or seeing a psychologist and was in danger of breaching probation for non-compliance with her conditions. This non-compliance created difficulties for her relationship with her probation officer, who was pressuring her to comply with the conditions. This situation also created tensions in her relationship with her mother, who was concerned that Jacey would face another court appearance, and who was frustrated by Jacey's refusal to take any action in this area.

Both the Youth Support Coordinator and her mother encouraged Jacey to see a psychologist and, after several failed attempts, she reluctantly agreed. The psychologist reported that Jacey was suffering from depression, had a suspected sleep disorder, could not manage in a school setting as it was too socially demanding, and recommended that she be 
referred to a psychiatrist. The psychiatrist identified her as clinically depressed and she was given medication to help manage her depression.

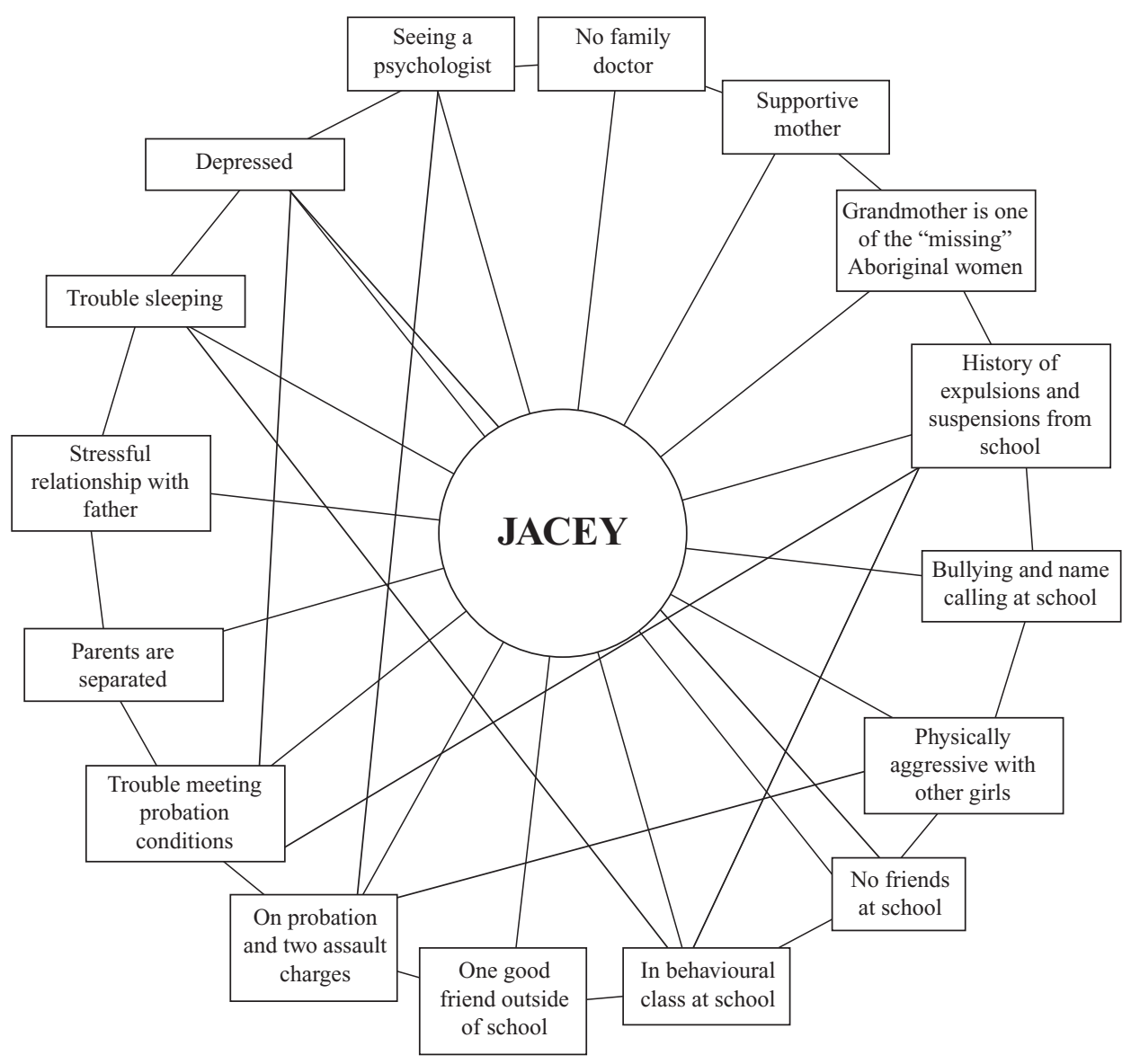

At the same time that Jacey and her mother were trying to navigate the criminal justice system, they were also struggling to deal with the education system. Again, Jacey's interactions with these systems has impacted her relationships, particularly with her mother, her teacher, and other students at school. Jacey had been expelled from three previous schools for fighting with other girls and had missed a considerable amount of school over the past two years. Jacey's mother was getting increasingly frustrated by Jacey's lack of attendance at school. Jacey either could not get up for school because she did not sleep at night, or she simply refused to go. Jacey reported that she had no friends at school, that other girls called her names, and that she hated attending the behavioural class at her school. Neither Jacey nor her mother could figure out how to deal with the situation. 
The Youth Support Coordinator accompanied Jacey and her mother to a school Attendance Board hearing. Despite the recommendation from the psychologist that Jacey could not handle the social demands of school, the Attendance Board ruled that Jacey must attend the school that she was registered in. However, Jacey still refused to go to school. Since the Attendance Board's ruling also included an order requiring her mother to send Jacey to school or face a possible fine, the ruling further strained the relationship between Jacey and her mother.

Given Jacey's refusal to go to school, her mother's inability to force her to go, and the recommendation of the psychologist that school was too socially demanding, the Youth Support Coordinator began to explore other education options for Jacey. The option that seemed the most accessible, and the one that Jacey preferred, was the Aboriginal Outreach Program, an Edmonton Public School program that provides educational instruction for youth in their home. This option was eventually accepted by the Attendance Board.

Jacey is now enrolled in this program. She meets regularly with her teacher and arrangements have been made by Pohna to provide a tutor for extra support. Jacey indicated that she would like to continue with this arrangement and her mother has enrolled her in the program for the next school year. While this education option seems to be yielding some positive results, her overall mental health is still a concern. She continues to suffer from depression and needs support in order to ensure that she follows through with counselling and treatment.

\section{John: Minor Charges ANd The Extrajudicial SAnCtions Program}

John, age 13, was referred to Pohna by a social worker with the EPS' Neighbourhood Empowerment Team Program (NETeam). He has two charges on his criminal record as a result of stealing bicycles: theft under $\$ 5,000$ and possession of stolen property under $\$ 5,000$. He was referred by the Court to the Extrajudicial Sanctions Program to deal with these offences. As such, he has been given an opportunity to complete agreed upon consequences as an alternative justice measure to court proceedings and sentencing.

As the Youth Support Coordinator worked to develop a relationship with John and gain some understanding of John's life, the challenges he faced, the strengths he held, and the support he had to draw upon, the following picture emerged as illustrated in the chart below.

Although John just turned 13, he has been associating with peers engaged in criminal activity, and has himself been involved in criminal activity since he was 11 years old. These associations and activities have resulted in the involvement of Children's Services and placement at the Yellowhead Youth Centre and Oak Hill Boys Ranch. He has also faced great difficulties at school and has a history of suspensions and expulsions. When he returned from Oak Hill Boys Ranch, it was a challenge to find a school that was able to deal with his aggressive and defiant behaviour.

Fortunately for John, he also had a number of supports that were working with him before he became involved with Pohna. Children's Services was providing support to John and his mother. The NETeam also provided support and were instrumental in getting him involved 
in the development of the Spoke Program. This program, a partnership with the EPS, the City of Edmonton, and bike dealers in the city, engages youth to fix and refurbish lost and unclaimed bikes, making them available to other youth in the city.

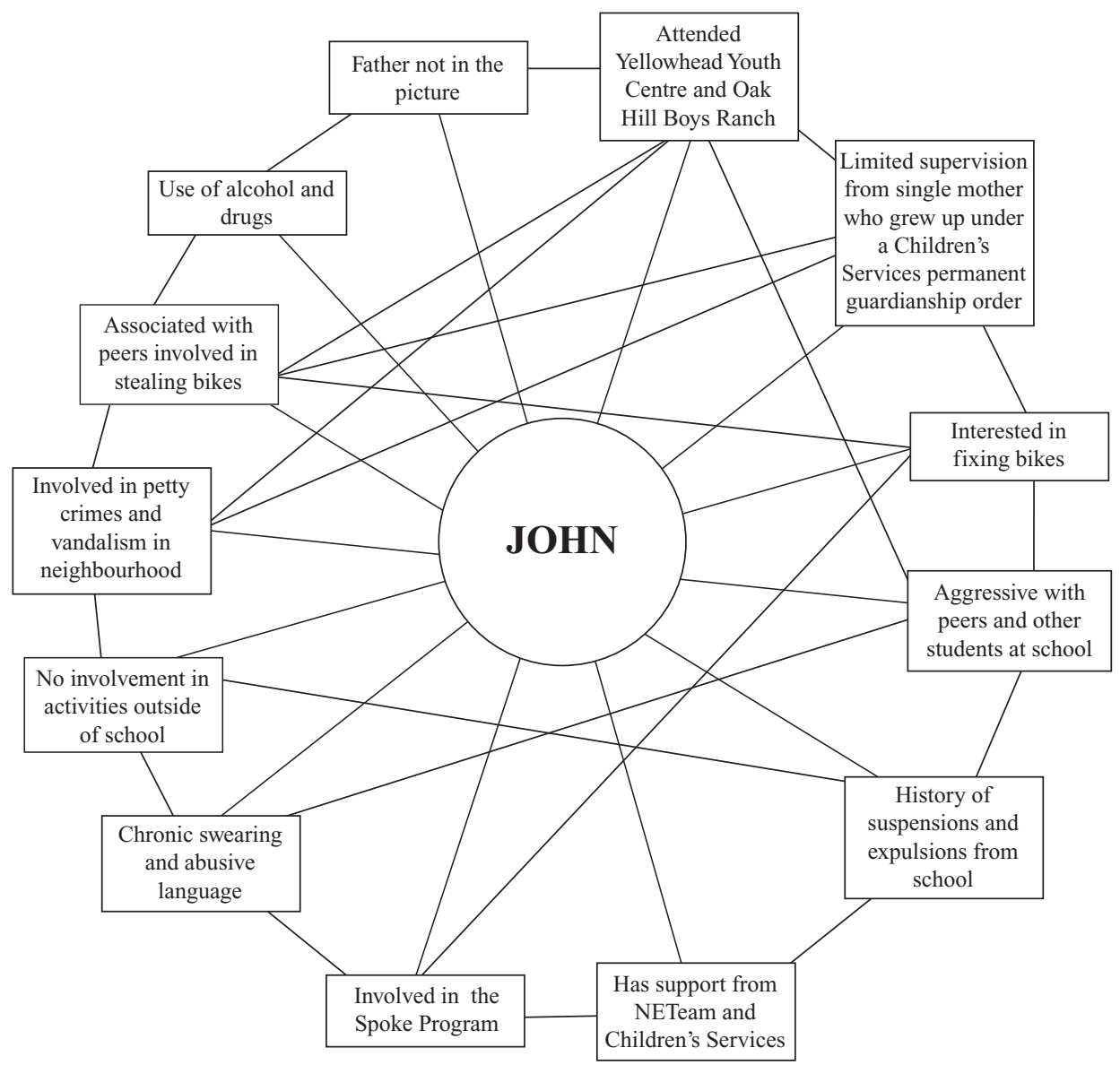

Despite these supports, John continues to face difficulties at school and in the community. At school he often interacts aggressively with peers and needs to be closely supervised to prevent situations from escalating. In the community, he has been involved in acts of vandalism and continues to associate with peers involved in similar anti-social activities and petty crimes.

Given that there were a number of agencies and helpers involved in John's life, the Youth Support Coordinator has not only worked to develop a relationship with John, but also with the people in his life. One of the key intervention strategies employed with John was to hold 
a Circle of Support that brought him together with these people. Within the Circle each person was asked to share their hopes for him, their fears for him, the strengths they saw in him, and their commitment to him. The Youth Support Coordinator will work with John and will use this information to build his support plan and help him move forward. Given his age and experience, helping him develop a sense of agency will be a challenge.

\section{E. SAM: No Criminal ACTIVITY, But Other RiSk FACTORS}

Sam, age 14, was referred to Pohna by his School Resource Officer. He was referred to the program because he was hanging out with peers who were stealing from vehicles, had family members who were involved with gangs, and was on the brink of expulsion. The School Resource Officer thought that, without intervention and support, Sam would likely be led into more serious criminal activity. As the Youth Support Coordinator worked to develop a relationship with Sam and gain some understanding of Sam's life, the challenges he faced, the strengths he held, and the support he had to draw upon, the following picture emerged:

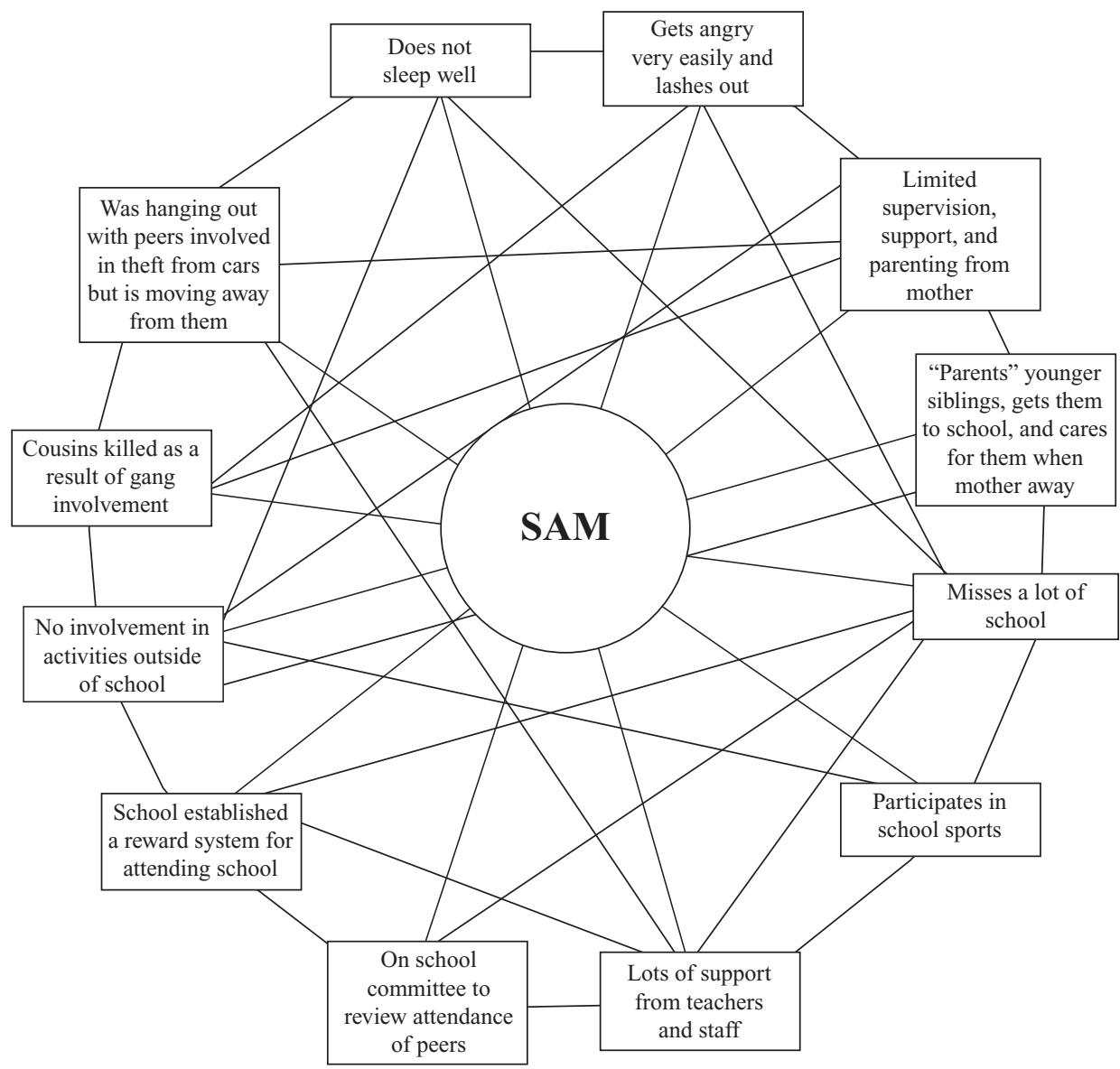


Although Sam was associating with negative peers and was on the fringe of criminal activity, the major issue pressing down on him was his lack of attendance at school. He seemed to like school and was engaged, particularly in sports and physical activity, but he was seldom there. He was also capable of completing his course work, but he was barely passing. Despite a good deal of support from the teachers and staff, Sam was before the Attendance Board for the third time. His mother did not attend any of the Board hearings and Sam went on his own. At previous Attendance Board hearings, Sam had agreed to follow the Board's recommendations but never followed through.

Given this situation, attendance at school became the focus of the work and of the relationship building between Sam and the Youth Support Coordinator. The only day that Sam regularly attended school was Friday because that was also the day that Sam got to play hockey. Friday became the focal point of the interaction between Sam and the Youth Support Coordinator. The Youth Support Coordinator attended Sam's practices and games. They talked about hockey and school and gradually worked out a plan whereby Sam would try to attend school more regularly. When Sam met his weekly goals for attendance, the Youth Support Coordinator would reward his behaviour by taking him out to eat or to a special event. One of these events included participating in the 118 Ave. Street Hockey Tournament, where Sam won a player of the game award.

Another support that the Youth Support Coordinator offered to help Sam improve his attendance was picking him up in the morning and taking him to school. Some mornings, the Youth Support Coordinator also dropped Sam's younger siblings off at their school. As the trust and relationship between Sam and the worker developed, Sam explained that he was often late or missed school because he had to get his siblings ready for school, take them to school by bus, and then take another bus to his own school. He would make sure that his siblings slept in their clothes to save time in the mornings, but this did not always work. Sometimes he just did not feel up to the journey or have the energy to get to school.

While all of this was happening, Sam and his mother faced the reality of an Attendance Board hearing. To help them prepare for this hearing, the Youth Support Coordinator convened a Circle of Support around Sam. The participants in the Circle included Sam, his mother, the School Resource Officer, and two of Sam's teachers. The focus of the Circle was to support Sam's efforts to increase his attendance and give a positive report to the Attendance Board. The Circle contained four rounds in which everybody shared their hopes that they held for Sam (and that Sam held for himself), the fears and concerns that they had about him, the strengths that they saw in him, and their commitment to support him in attending school more regularly. This process allowed Sam to both see and experience that he was valued and that, while he was ultimately responsible for going to school, there were others there to support his efforts.

Before the end of the school year, Sam won an attendance award, along with an award in physical education. His marks in three subjects also increased by 20 percent. To celebrate his success, the Youth Support Coordinator took him to the Edmonton Oilers' last home game. 
While Sam no longer needs to report to the Attendance Board, his struggles are not over. His mother has made attempts to help Sam get his siblings to school, but often the responsibility still falls on Sam. The Youth Support Coordinator continues to meet with Sam and occasionally drives him to school, but this is becoming increasingly unnecessary. He is often unable to participate in sports after school because he has to care for his siblings. The care he extends to his siblings is a strength to be recognized, but he still needs help to find balance in his life.

\section{LESSONS LEARNED AND IMPLICATIONS For Practice ANd Program Design}

While the general orientation, approach, and goals have remained constant throughout the implementation of the program, the practices and interventions have changed and evolved as the program design was met with the realities of the youth and families engaged in the program. As such, Pohna is not a program that has been designed to follow a specific blueprint, but is instead guided by principles and evidence of good practice. It adapts to changing realities - realities that, while anticipated, cannot really be known until they are faced.

\section{A. Colby: Untangling the Web, Overcoming the Past}

While the focus of Pohna is to help youth identify their strengths and interests and to develop goals for their future, neither the youth nor the Youth Support Coordinator can avoid the consequences of past behaviour. For example, in the case of Colby, his future was in many ways marked by his past. Colby had great difficulty meeting the conditions of his probation. Indeed, 15 of his 30 charges were related to probation breaches. Meeting the conditions of his probation is not negotiable. However, the manner in which these conditions are met can be influenced by Colby's strengths and interests. Colby can have a say and some agency over how he meets these conditions. The Youth Support Coordinator worked with Colby to help him see that attending school regularly, meeting regularly with the Youth Support Coordinator, and completing community service hours would not only help prevent more charges, and possibly incarceration, but could be a springboard to a better future.

The Youth Support Coordinator worked with Colby to reframe the conditions of his probation. They worked towards viewing Colby's conditions as possibilities rather than punishments. While meeting the conditions of his probation, Colby is also developing new relationships and interactions with others. He is learning to build a bridge between his past lifestyle and associations and the new ones that he wants to create. He is learning that he can influence his future and engage in new activities not because he has to, but because he wants to.

For youth like Colby, criminal activity is not so much a series of individual acts as it is a gradual adoption of associations and a lifestyle that leads to more criminal activity. How do you change all of this if you have a history of criminal activity and if your friends are involved in criminal activity? How do you find new friends? How do you learn to engage in new activities? How do you learn to interact with people in a different way? How do you develop a sense of agency and control over your life? If we are to help youth like Colby we 
need to create practices that help them move away from being defined and constrained by their past lifestyle and towards the development of the self-agency needed to be more proactive, and less reactive, to the challenges and situations facing them.

\section{B. Dania: Keeping the Hope of Change Alive, Tracking Small Steps of Progress}

While youth facing serious issues and involvement with the criminal justice system may want to change, the forces within their lives can derail these desires. Their intentions alone cannot create the change needed. Adolescents cannot "will" their way to change. They need ongoing adult support and guidance.

The issues identified in Dania's case study, particularly her struggles with alcohol, are fraught with complexities. Creating change involves both success and failure. The challenge for both Dania and her Youth Support Coordinator is to remain optimistic that change is possible. If we are going to support youth like Dania, we need to accept the fact that change can be a slow process that involves steps back as well as forward - change is a process and not an end point. We need to develop practices that identify and measure the smallest steps towards change to keep the possibility of gradual change alive and help Youth Support Coordinators develop the stamina to continue to support youth despite setbacks and a "lack of progress."

\section{JACEY: NAVIGATING INTERACTIONS WITH SYSTEMS}

A large portion of the interaction between Jacey and her Youth Support Coordinator focused on dealing with the demands and pressures coming from the education and criminal justice systems. The interventions described in her case study helped Jacey navigate through the complexities that she faced in interacting with the education and criminal justice systems. However, the sources of her depression, the loss and trauma in her life and the tensions and struggles in her relationships with her family, friends, and other significant adults, remains tangled. There is more untangling to be done, particularly in terms of her relationships and sense of connectedness to her family and community.

The process of developing goals and support plans with youth is multifaceted and dynamic. As Jacey has taught us through our work with her, if we are to help her become more self-determined and actively involved in directing her future we need to examine and fine-tune the practices that help youth navigate the complex systems that impact their lives. We also need to develop practice that help them build, maintain, and repair healthy relationships, which they need in their lives in order to feel a sense of connection to others.

\section{John: Developing A SENSE OF AgenCy ANd CONTROL}

While Pohna works to ensure that youth drive the program and develop their own support plans, youth as young as John tend to share what they think adults want to hear. Often they have not experienced being listened to by adults or do not believe that adults really care about what they think. In some cases they have been punished rather than held accountable for their behaviour. This is a subtle yet important difference. Punishment tends to negate a 
sense of personal agency. Power is in the hands of the punisher, not the punished. However, accountability can highlight the importance of personal agency and the ability of people to overcome past mistakes. The focus should be on the future and moving ahead rather than the past.

A Circle of Support by its very nature tends to ensure that youth are perceived to be heard, and are in fact listened to. While the Circle focuses on the situation surrounding the youth, it is not a confrontation and the youth is not judged. A talking piece is used to regulate the dialogue of the participants. Only the person holding the talking piece may speak. It allows the holder to speak without interruption and allows the listeners to focus on listening and not on thinking about a response to the speaker. The use of the talking piece allows for a full expression of emotions, thoughtful reflection, and an unhurried pace. The talking piece is a powerful equalizer. It allows every participant an equal opportunity to speak and carries an implicit assumption that every participant, particularly the youth, has something important to offer.

The Circle helps to immerse youth in an experience in which their thoughts are shared and heard in a respectful manner. It also helps to give youth the experience of receiving advice and support from adults that is not imposed, but offered. In the end, it is the youth who must decide what information is meaningful and how it will help them make the changes that they want to create in their lives. The challenge is to expand this experience to other areas of their life. To meet this challenge we need to develop practices that encourage the adults surrounding them to find a balance between supporting and guiding the youth, and empowering them to take responsibility for their own choices and actions.

\section{E. SAM: ENTERING THE WORLD OF YOUTH}

The practice of supporting youth like Sam requires the Youth Support Coordinator to fully enter the reality of Sam's life. We often make assumptions about the behaviour of youth: they do not attend school because they do not think that it is important, they do not attend school because it takes work, they do not like school, or they do not fit in. These were not reasons for Sam's lack of attendance at school. He did not attend because he was responsibile for getting his siblings to school and had to make it there largely on his own.

Sam seemed to accept his mother's limitations and worked around them. This called upon the school and the Youth Support Coordinator to do the same. As the school learned more about the reasons behind Sam's attendance problems, they accommodated him. Rather than drawing attention to the days he was late, they welcomed and supported him when he came to school. Recognizing Sam's efforts to care for his siblings, the Youth Support Coordinator drove Sam and his siblings to school. While the Youth Support Coordinator also talked to Sam's mother about the issue and encouraged her to help get her kids to school, this did not become the focus of his work. Like Sam, he worked around the mother's limitations. Both the school and the Youth Support Coordinator did what was needed in order to support Sam.

For parents like Sam's mother, the presence of Youth Support Coordinators and notices from school Attendance Boards are, by their very nature, invasive. They come between one of the most personal relationships that exist: the relationship between a parent and their child. 
In this instance, it is almost impossible to neither feel judged nor inadequate. Yet at the same time, raising children is not a solitary task; it requires support from others. In most instances this support comes from family and friends, who have a relationship and a sense of responsibility to offer help when it is needed. As such, it is more likely to be accepted and not seen as an invasion.

Rather than responding to Sam and his mother through sanctions and the traditional roles of a professional relationship, both the teachers at the school and the Youth Support Coordinator found a way of offering help that was more supportive than judgmental, and more facilitative than corrective. While Youth Support Coordinators are not family or friends, they cannot, as this case study reveals, rely solely on professional or therapeutic relationships to offer the help that youth and their families need. As Sam and his mother have taught us, intervening in the lives of youth and their parents requires a different sort of practice. Within Aboriginal communities, aunts and uncles are often called upon when relationships between youth and their parents are troubled or when parents require support to care for their children. To help articulate this practice, we need to examine the traditional role of aunts and uncles within Aboriginal teachings to inform our practice. Perhaps in this way we can develop interventions in the lives of at risk youth and their families that are both facilitative and supportive, while recognizing the boundaries and respecting the very intimate relationship between parents and their children.

\section{Referral Process}

In the initial program design, referrals to the program were to be made by the EPS. This was because the EPS were in the best position to initially identify a group of youth that they felt were most at risk of criminal activity and gang involvement; exactly the type of youth that we wanted to direct to the program. While this rationale is still sound, we have found that, in practice, the process of identifying these youth and then referring them to Pohna has created more demands on the service than we originally anticipated, demands that have slowed down the referral process.

In response to this issue, Pohna worked with the EPS to embed a Youth Referral Coordinator within their Eastwood detachment who can assist police members in making referrals to the program. This eventually led to an increase in the volume of quality referrals. In addition, Pohna has opened up its referral process and is now accepting referrals from other agencies in the community, directly from youth, and from families.

\section{ENGAGING AND SUPPORTING FAMILIES}

The well-being of the youth that Pohna targets is highly influenced by the health of their relationships with their family (immediate and extended) and the overall well-being of their family. As a rule of thumb, where there is conflict and dysfunction in the family, youth are more at risk and vulnerable. Conversely, where families have supportive relationships and healthy lifestyles, youth are less at risk and vulnerable.

In the early days, Pohna staff experimented with a variety of ways to support both youth and their families. They quickly learned that this led to a tension that made it difficult for the 
Youth Support Coordinators to support and advocate for the youth and their families as one when dealing with complex situations. The initial response was to hire a dedicated family worker that could be called in to assist workers in these situations. Staff quickly concluded that the degree of complexity in family situations exceeded the ability of any one person to address, and that families needed access to a broader and more robust array of services. Pohna is now in the process of making adjustments to the manner in which they support the families in the program. One adjustment is to have youth workers connect families-in-need to the services of the NCSA Wellness Centre so that they can provide wrap around services to families. This should allow support to be provided to the families while allowing youth workers to maintain their focus on supporting and advocating for the youth.

\section{DEALING With Youths’ VuLnerability CONTEXT}

The efforts of youth and their Youth Support Coordinators to build resiliency and to resist the temptation of becoming involved in gangs does not happen in a vacuum. Youth exist within a broader context that makes them vulnerable, which involves a variety of patterns, trends, systems, and shocks. ${ }^{11}$ A "vulnerability context" is a "range of external factors and forces that directly or indirectly, positively or negatively, shapes everyone's environment." 12 As the case studies revealed, the lives of youth involved in Pohna are both fragile and complex. They have fewer skills, resources, and positive networks to cope with external stresses and shocks. Their immediate environment is often filled with temptations such as money promised by criminal activities, and negative influences such as family involvement in gangs. They are often caught up in navigating the demands of external systems such as criminal justice and education at the same time. Parents are often struggling with their own issues and history of abuse and neglect. To effectively support the youth involved in Pohna, we need to understand and address the broader forces at work that both strengthen and undermine their resiliency. Only then can we begin to identify strategies for long-term change.

Program staff have determined that they spend far more time helping clients cope with their vulnerability context than they first anticipated. In reflecting on the vulnerability context of youth participating in Pohna, program staff, administration, and partners identified three consequences. First, the context created a "negative spiral" where Youth Support Coordinators ended up continuing to provide comprehensive support on their own because they did not have time to complete a plan to broker in others. Second, Youth Support Coordinators helped youth cope with their situation, but on their own they could not offer the range of supports and opportunities available through the broader community and service

11 Patterns and cycles are "long-established repeating patterns connected to the changing stages" in the lives of at risk youth, "their roles and responsibilities in the family, their relationships and seasonality." Trends are "broader social, economic and political forces and changes that emerge over time" and can have serious impacts on the security of an at risk youth. Systems are "the formal and informal ways that society" or formal systems function, including the cultural biases, attitudes, and sentiments that shape the decisions and behaviours of organizations. Shocks are "sudden or catastrophic occurrences" that can undermine resiliency. They can be random events such as a violent death in the family or an arrest, but "they can also be the culmination of negative effects in cycles, trends and systems": Women and Economic Development Consortium, Women in Transition out of Poverty: An Asset-Based Approach to Building Sustainable Livelihoods (Toronto: Canadian Women's Foundation, 2001) at 27, online: Canadian Women's Foundation <http://www.cdnwomen.org/PDFs/EN/CWF-WIT-asset.pdf>. Ibid. 
system. Finally, the youth and Youth Support Coordinators spent a great deal of time and effort responding to and navigating within and around systems.

While the vulnerability context is a useful lens with which to illuminate all of the contextual variables that influence the well-being of youth, it is also helpful to understand why Youth Support Coordinators spend a far greater than anticipated amount of time working with youth to cope or manage with crises, unproductive patterns, shocks, and systems. This includes spending time attending, identifying, and contacting other service providers; learning about and navigating their systems; dealing with crises brought on by a shock such as a violent confrontation with a family member or the death of an aunt; or simply driving a youth to a recreational program in another part of the city because it is one of the few opportunities available that they find meaningful and accessible. ${ }^{13}$

\section{Conclusion: ACTION, LeARning, AND CHANGE}

The NCSA and its partners spent a great deal of time, research, and thought designing an integrated program that would respond to youth engaged in criminal activities and gang association. While this "up front" work was necessary, the same thoughtful care and attention needed to extend to the operation and implementation of the program. While the program design was based on a great deal of firsthand experience, research, and consultation, the practical elements of the program have yet to be developed, tested, and eventually refined through action.

Given this reality, Pohna used a developmental approach to evaluation ${ }^{14}$ in which the methodology is driven by a process of trial and error, through which program decisionmakers test oftentimes well-thought-out ideas about the nature of the problem and how to address it in the complex laboratory of the real world. It is embedded in the idea that social challenges, such as participation in gangs, are sufficiently complex that pre-designed, recipelike interventions are apt to fail and that program designers and implementers must be prepared to adapt the program based on experience. The aim of developmental evaluation is to ask probing questions, encourage the gathering and systematic use of data when making program decisions, track results in order to provide feedback, and support program adaptations along an emergent path.

New programs like Pohna require adjustments and, in some cases, radical restructuring to reflect what is learned. It requires program staff, administration, and partners to conscientiously examine our practices and make informed decisions about what is working and what is not, what new issues are emerging, and the impact that they have on our service. As this article has shown, we have and will continue to make adjustments to the program as we gain a deeper understanding of the complexity of the lives of youth involved in Pohna. Given this complexity, there is no simple or straightforward "answer" to the problem of youth involvement in criminal activity and gangs. However, we have the ability to make our programs and interventions more effective if we begin to focus our attention on learning from

See LaBoucane-Benson et al., supra note 5.

See e.g. Michael Quinn Patton, Developmental Evaluation: Applying Complexity Concepts to Enhance Innovation and Use (New York: Guilford Press, 2011). 
the youth and our interactions with them. We need to learn to create new realities for youth from the realities that they live with, and that includes their interactions with us as supporters. In the end, all we can do is take the best course of action we know, use critical thinking to reflect on this action, make adjustments to our practices and programs, and then move on. 